it will allow public comment on its controversial proposal to strip the grey wolf of its federal protection. The agency wants to remove the animal from the list of those protected under the 1973 Endangered Species Act, and to hand responsibility for its management and conservation to individual states. The FWS claims that the move follows the "successful recovery" of the wolf in two key regions. Scratch the surface, though, and it looks more like a cost-cutting exercise and, to some, a politically convenient one. Gary Frazer, assistant director for endangered species at the FWS, told Nature that he expects hundreds of thousands of people to comment.

Many of these will be rightly suspicious of the true motives. The proposed delisting of the grey wolf comes barely two years after the notorious 'wolf rider' that saw a clause to remove legal protection of the animals in Montana and Idaho tagged by local politicians to an unrelated, and essential, budget appropriations bill. The move, this journal noted at the time, set a "dangerous precedent" (see Nature 475, $5 ; 2011$ ), and was the first time that Congress had removed a species from the list. The clumsy political manoeuvre came after a decade of court-rebuffed attempts to change the status of the wolf through the proper regulatory channels.

Grey wolves are certainly doing better in the United States than a century or so ago, when rewards for their killing made them locally extinct. Controlled reintroduction under the 1973 act has led to populations in the thousands around the Great Lakes and Northern Rockies - and to the loss of livestock. According to the US Department of Agriculture, between 1995 and 2007, wolves killed 298 cattle, 46 sheep, 13 llamas, 24 goats and 7 horses in Montana. Enough is enough, critics say; the grey wolf is no longer endangered. Yet the 1973 act is clear: such a judgement must be made over all, or a significant proportion, of the animal's range.

"We still haven't figured out how to handle a situation where experts have outspoken views," Frazer says of the divergent opinions on the

topic. It is a lament that will strike a chord with many policy-makers, not least those in Britain, where government-sanctioned marksmen are busy reducing the population of another emblematic - and previously protected - species. After years of similar arguments and conflicting scientific advice, the environment department DEFRA has embarked on two pilot culls of badgers, which farmers blame for the spread of bovine tuberculosis (TB).

Ian Boyd, science adviser to DEFRA, writes on page 159 that, too often, the evidence used to set policy is biased and unreliable, even

"Enough is enough, critics say; the grey wolf is no longer endangered." lished evidence on badger culls does not indicate that bovine TB will be reduced by DEFRA's strategy, which relies on untested tactics such as free shooting.

Politics can trump science, of course, for politicians are elected to make decisions. But so can sentiment. A few miles along the M4 motorway from where the badger culls and the protests against them are under way is the base of the Wolf Conservation Trust. Wolves vanished from Britain centuries ago, but they retain mystique and appeal - even to Brits. US lawmakers must bear this in mind as they invoke science to argue for the delisting of the grey wolf.

The protection of the 1973 Endangered Species Act for vulnerable animals does not end at the US border. Several overseas and foreign species are listed too, and US citizens are forbidden from, for instance, trading in them. But a US law that gives sanctuary to the Chinese alligator and the great Indian bustard but not to the native grey wolf would be a strange beast indeed.

\section{Reality at risk}

\section{Don't treat a memoir as anything other than one person's interpretation of events.}

"I t was the afternoon of my eighty-first birthday and I was in bed with my catamite when Ali announced that the archbishop had come to see me." So runs the first sentence of Earthly Powers, Anthony Burgess's memoir of the fictional novelist Kenneth Toomey. "I have lost none of my old cunning in the contrivance of what is known as an arresting opening," he writes a few lines later - noting that, whereas every supposed fact in the first sentence is true, the context is one of pure artifice, designed to portray an image of the writer as he would wish to be seen, not necessarily as he really is. Toomey is clearly a writer of some skill (as is Burgess, his inventor and rapporteur), so we, the poor readers, are at his mercy. We can do no other than take what he claims as truth at face value, whether it is true or not. Such is the caveat emptor of the memoir in general.

This week, Nature publishes book reviews of two memoirs by very real people. On page 162, Robert Crease reviews My Brief History by theoretical physicist Stephen Hawking, and notes that it is more akin to a PR exercise than a warts-and-all confession: "It does not take the reader behind any scenes ... It is a concise, gleaming portrait, not unlike those issued by the public relations department of an institution." Eugenie Scott on page 163, by contrast, finds An Appetite for Wonder, the first volume of memoirs by evolutionary biologist Richard Dawkins, "a very honest book", in which we get a taste of the upbringing and early experiences of the author of The Selfish Gene and The God Delusion. From which we are entitled to get a flavour, at least, of how Dawkins got to be the man he is today - in other words, what makes him tick.
But do we? Get a flavour of what makes someone tick from their own, self-selected, self-redacted reminiscence? Memoirs are more vehicles of entertainment than any reflection of reality. When one reads The Double Helix, James Watson's knockabout account of the discovery of the structure of DNA, one should take any facts presented therein strictly as having been heavily filtered by the unashamedly biased reminiscence of just one of the protagonists, not as a scholarly account. And there's nothing wrong with that. The Double Helix works beautifully as entertainment.

There is another layer of selection. Those memoirs that get published as books are not so much about scientists (say) as celebrities. Readers of My Brief History will want to know about Hawking's triumph over his disability more than how he came to this or that conclusion about black holes. More people are likely to have encountered Dawkins as the doctrinaire neo-atheist of The God Delusion than as the peerless commentator on the machinery of evolution in The Selfish Gene - and vastly more than as the author of scientific papers on animal behaviour.

To understand what working scientists free from the constraints of celebrity actually do all day, one might turn to the blogosphere and follow (to mention just two of thousands) Jenny Rohn's 'Mind the gap' (http://occamstypewriter.org/mindthegap) and, perhaps more pertinently, the notes of the anonymously eponymous Female Science Professor (http://science-professor.blogspot.co.uk).

Even then, such writings demonstrate the self-selection of those scientists (a tiny proportion) who feel that they have something to say. For everyone else, life is something that is lived undocumented, unshared and in real time. Perhaps the only really 'true' experiences are those that one has lived oneself. To which one can $\rightarrow$ NATURE.COM To comment online, click on Editorials at: go.nature.com/xhunqv only ask whether one is talking to oneself, or whether the Universe has gone solipsistic all of a sudden. Then again, to quote that koan from Jewish Buddhist wisdom - if there is no self, whose arthritis is this? 